\title{
Histopathological Study on Pattern of Prostatic Diseases in Patients Admitted at a Medical College.
}

\author{
Dhirendra Kumar ${ }^{1}$, Prabhat Kumar Lal ${ }^{2}$, Pawan Kumar Chaudhary ${ }^{3}$, R V N Singh ${ }^{4}$ \\ ${ }^{1}$ Tutor, Department of Pathology, Vardhman Institute of Medical Sciences, Pawapuri, ${ }^{2}$ Assistant Professor, Department of Community Medicine, Darbhanga Medical \\ College, Darbhanga, ${ }^{3}$ Professor \& Head, Department of Pathology, Vardhman Institute of Medical Sciences, Pawapuri, ${ }^{4}$ Professor, Department of Pathology, \\ Vardhman Institute of Medical Sciences, Pawapuri.
}

\section{Abstract}

Background: Benign prostatic hyperplasia is common in elderly males, while accidental finding of prostatic carcinoma in TURP specimen is also not uncommon in this age group. Subjects and Methods: The present hospital based cross-sectional study was done to find the various histopathological patterns of the prostatic lesions seen in transurethral resection of prostate (TURP) specimens at a tertiary care center. Histopathological examination was done to observe the type and morphology of these lesions. Results: $90 \%$ of the patients suffered from benign prostatic hyperplasia while prevalence of carcinoma of prostate in TURP specimens was 5\%. Conclusion: Routine histopathological examination of TURP specimen is helpful in diagnosing the undiagnosed cancer.

Keywords: Histopathology, Pattern, Prostate, TURP.

Corresponding Author: Dr. Prabhat Kumar Lal, Department of Community Medicine, Darbhanga Medical College, Darbhanga, Bihar.

Received: January 2019

Accepted: January 2019

\section{Introduction}

Prostatic disorders are an important cause of morbidity and mortality in elderly males. ${ }^{[1]}$ The most common urological disorder encountered after fourth decade is benign prostatic hyperplasia (BPH). While it affects only $8 \%$ of males during their fourth decade, its prevalence reaches $75 \%$ by the eighth decade of life. ${ }^{[2]}$

The other lesion seen in elderly males is prostatic carcinoma. It is the most commonly diagnosed malignancy in this group and also the second leading cause of cancer related deaths in men older than 50 years. ${ }^{[3]}$ In India, 5\% of all male cancers is prostatic cancer. While autopsy studies have reported the prevalence of the disease to be $30 \%$ in men above 50 years, foci of adenocarcinoma has been present in virtually all men after 90 years. ${ }^{[4]}$

The prevalence and pattern of prostatic illness is helpful in proper management of these cases. Hence, this study was conducted.

\section{Aims \& objectives}

The present study was done to find the various histopathological patterns of the prostatic lesions seen in transurethral resection of prostate (TURP) specimens.

\section{Subjects and Methods}

The present study was hospital based cross-sectional in nature conducted at a tertiary care center. The patients admitted at the tertiary care center, found to be suffering from prostatic enlargement and undergoing TURP or tru-cut needle biopsy were included in the present study. Those with diagnosed prostatic malignancy and those refusing surgery were excluded. Clinical details of patients including history and clinical examination were noted in the pretested proforma. A total of 60 patients were included in the present study.

The specimens obtained after TURP of these patients were received in the department of Pathology and were fixed in $10 \%$ formalin. The volume of specimen was assessed. Initial $12 \mathrm{cc}$ of specimen was processed in toto. If the volume was more than $12 \mathrm{cc}$, additional material was processed in the blocks of $5 \mathrm{cc}$. Paraffin-fixed tissue sections were cut in thicknesses of $5 \mu$ and stained routinely with hematoxylin and eosin.

Different types of BHP were described as per Franks classification. ${ }^{[5]}$ The prostatic tumors were classified according to WHO classification and the adenocarcinomas were graded histologically according to the Gleason's system. ${ }^{[6-7]}$ Data were entered in Microsoft excel 2007 and analyzed using Statistical Package for Social Science (SPSS, version 16) for Windows.

\section{Results}

A total of 60 patients of prostatism were studied. [Table 1] shows the findings of histological examination of the specimen. $90 \%$ of the patients suffered from benign prostatic hyperplasia (PIN). One case each of atypical 
adenomatous hyperplasia was seen (1.7\%). $3.3 \%$ cases of prostatic intraepithelial neoplasia were seen. The prevalence of carcinoma of prostate in TURP specimens was 5\% and all the cases were adenocarcinoma.

Among the cases with benign prostatic hyperplasia, 22 cases (36.7\%) had BPH with prostatitis and 31 cases (51.7\%) were without prostatitis. Among the cases with prostatic intraepithelial neoplasia, one case $(1.7 \%)$ had lowgrade prostatic intraepithelial neoplasia while equal number $(1.7 \%)$ had high-grade prostatic intraepithelial neoplasia.

\begin{tabular}{|c|c|c|c|c|}
\hline $\begin{array}{l}\text { Prostatic } \\
\text { pathology }\end{array}$ & Subtypes & Frequency & $\%$ & $95 \% \mathrm{CI}$ \\
\hline \multirow{2}{*}{$\begin{array}{l}\text { Benign Prostatic } \\
\text { Hyperplasia } \\
(n=54)\end{array}$} & $\begin{array}{l}\text { Without } \\
\text { prostatitis }\end{array}$ & 31 & 51.7 & $\begin{array}{l}39.3- \\
63.8 \% \\
\end{array}$ \\
\hline & $\begin{array}{l}\text { With } \\
\text { prostatitis }\end{array}$ & 22 & 36.7 & $\begin{array}{l}25.6- \\
49.3 \% \\
\end{array}$ \\
\hline $\begin{array}{l}\text { Atypical } \\
\text { Adenomatous } \\
\text { Hyperplasia }\end{array}$ & - & 1 & 1.7 & $0.3-8.9 \%$ \\
\hline \multirow{2}{*}{$\begin{array}{l}\text { Prostatic } \\
\text { Intraepithelial } \\
\text { Neoplasia }(n=2)\end{array}$} & LGPIN & 1 & 1.7 & $0.3-8.9 \%$ \\
\hline & HGPIN & 1 & 1.7 & $0.3-8.9 \%$ \\
\hline $\begin{array}{l}\text { Carcinoma of } \\
\text { prostate }\end{array}$ & - & 3 & 5 & $1.7-13.7$ \\
\hline
\end{tabular}

[Table 2] shows the findings of histopathological examination among cases with prostatitis $(n=54)$. Majority of the cases $(81.8 \%)$ had chronic prostatitis while $13.6 \%$ had acute prostatitis. There was one case $(4.5 \%)$ of granulomatous prostatitis.

Table 2: Findings in cases of prostatitis.

\begin{tabular}{|l|l|l|l|}
\hline Histopathology & $\begin{array}{l}\text { Frequency } \\
(\mathbf{n = 2 2})\end{array}$ & $\mathbf{\%}$ & $\mathbf{9 5 \%}$ CI \\
\hline Chronic prostatitis & 18 & 81.8 & $61.5-92.7 \%$ \\
\hline Acute prostatitis & 3 & 13.6 & $4.7-33.3 \%$ \\
\hline $\begin{array}{l}\text { Granulomatous } \\
\text { prostatitis }\end{array}$ & 1 & 4.5 & $0.8-21.8 \%$ \\
\hline
\end{tabular}

[Table 3] shows the histopathological changes in cases with benign prostatic hyperplasia. $72.2 \%$ cases had fibromyoadenoma, $22.2 \%$ had fibroadenoma, $3.7 \%$ had fibromuscular changes and stromal change was seen in one case $(1.9 \%)$.

Table 3: Findings in cases of Benign Prostatic Hyperplasia.

\begin{tabular}{|l|l|l|l|}
\hline Histopathology & $\begin{array}{l}\text { Frequency } \\
(\mathbf{n = 5 4 )}\end{array}$ & $\mathbf{\%}$ & $\mathbf{9 5 \%}$ CI \\
\hline Fibromyoadenoma & 39 & 72.2 & $59.1-82.4 \%$ \\
\hline Fibroadenoma & 12 & 22.2 & $13.2-34.9 \%$ \\
\hline Fibromuscular & 2 & 3.7 & $1-12.5 \%$ \\
\hline Stromal & 1 & 1.9 & $0.3-9.8 \%$ \\
\hline
\end{tabular}

Two cases of carcinoma prostate had Gleason score between 7-9 while one case each had scores of 1-3 and 4-6.

\section{Discussion}

The present study included 60 patients of prostatism. Histopathological examination revealed that the prevalence of benign prostatic hyperplasia was $90 \%$. Among the cases with benign prostatic hyperplasia, 36.7\% cases had BPH with prostatitis and $51.7 \%$ were without prostatitis. $72.2 \%$ cases had fibromyoadenoma, $22.2 \%$ had fibroadenoma, $3.7 \%$ had fibromuscular changes and stromal change was seen in one case (1.9\%). Begum et al found that $96 \%$ cases were benign. Glandulostromal pattern of hyperplasia was the most frequent pattern and stromal pattern of hyperplasia was least common. ${ }^{[8]}$ Sharma et al observed that $91.02 \%$ cases were having nodular hyperplasia (BPH). ${ }^{[9]}$ Puttaswamy et al observed that benign lesions constituted $80.6 \% .^{[10]} \mathrm{Bal}$ et al found that $87 \%$ cases had nodular hyperplasia. Fibroglandular was the most common type of BPH seen in their study. ${ }^{[11]}$ Angurana reported that BHP alone was seen in $50.5 \%$ cases. Fibroglandular hyperplasia constituted $78.5 \% .^{[11]}$ Bhat et al found that BPH was the commonest lesion (92.6\%) and was on many occasions associated with prostatitis. Fibromyoadenomatous pattern was seen to be the most common pattern of BHP. ${ }^{[12]}$ Bhatta et al reported that nodular hyperplasia was seen in $89.58 \%$ cases. ${ }^{[13]}$

Majority of the cases with prostatitis had chronic prostatitis $(81.8 \%)$ while $13.6 \%$ had acute prostatitis. There was one case $(4.5 \%)$ of granulomatous prostatitis. Begum et al found that BPH was associated with acute prostatitis in $4 \%$ and chronic prostatitis in $24 \% .{ }^{[8]}$

One case each of atypical adenomatous hyperplasia was seen $(1.7 \%)$. $3.3 \%$ cases of prostatic intraepithelial neoplasia were seen. Among the cases with prostatic intraepithelial neoplasia, one case $(1.7 \%)$ had low-grade prostatic intraepithelial neoplasia while equal number $(1.7 \%)$ had high-grade prostatic intraepithelial neoplasia. Sharma et al found that $5.71 \%$ cases were of PIN. ${ }^{[9]}$

The prevalence of carcinoma of prostate in TURP specimens was 5\% and all the cases were adenocarcinoma. Two cases of carcinoma prostate had Gleason score between 7-9 while one case each had scores of 1-3 and 4-6. Begum et al found that $4 \%$ cases suffered from prostatic carcinoma while Sharma et al found that $3.26 \%$ cases were malignant. ${ }^{[8,9]}$ Puttaswamy et al observed that premalignant and malignant lesions constituted $19.4 \%$. They reported that Gleason's score of 7 was the most common, seen in 36.3\% of cases. ${ }^{[10]} \mathrm{Bal}$ et al found that $10 \%$ specimen were positive for prostatic cancer. PIN had statistically significant association with cancer. ${ }^{[11]}$ Angurana reported that cancer was seen in $7 \%$ cases. $33.7 \%$ were graded in Gleason score 4-6 while $64.3 \%$ in Gleason score 7-10. ${ }^{[12]}$ Bhat et al found that prostatic adenocarcinoma was present in about $7.4 \%$ of all cases and majority of these cases were of high grade adenocarcinoma. ${ }^{[13]}$ Bhatta et al reported that malignant lesions were seen in $8.34 \%$ cases of all prostatic lesions. All the cases of prostate carcinoma were adenocarcinoma. The most frequent Gleason score was 9. ${ }^{[14]}$

Various reports have presented different findings regarding prevalence of prostatic lesions. However, BPH is the most common abnormality and prevalence of prostatic cancer ranges from $3 \%-17 \%$. 


\section{Conclusion}

$\mathrm{BPH}$ is present in $90 \%$ cases. About one-third of cases of BPH had prostatitis also. Prostatic carcinoma was seen in $5 \%$. All the cancers were adenocarcinoma. Routine histopathological examination of resected tissue will be helpful in screening for prostatic cancer.

\section{References}

1. Epstein JI, Allsbrook WC Jr, Amin MB, Egevad LL; ISUP Grading Committee. The 2005 International Society of Urological Pathology (ISUP) Consensus Conference on Gleason Grading of Prostatic Carcinoma. Am J Surg Pathol 2005;29:1228-42.

2. Rosai J. Male reproductive system. In: Rosai J, editor. Rosai and Ackerman's Surgical Pathology. 10thed. New Delhi: Elsevier, 2011:1287-1333.

3. Ro JY, Amin MB, Saihin AA and Ayala AG (2001). Tumors and timorous conditions of the male genital and urinary tract, Diagnostic Histopathology of Tumors 1 773-4.

4. Garg M, Kaur G, Malhotra V, Garg R. Histopathological spectrum of 364 prostatic specimens including immunohiostochemistry with special reference to grey zone lesions. Prostate Int 2013; vol 1 (4) : 146-151.

5. Franks LM. Benign nodular hyperplasia of the prostate; a review. Ann R Coll Surg Engl 1953;14:92-106.
6. Mostofi FK, Sesterhenn I, Sobin LH. Histological typing of prostatic tumours. In: International Histological Classification of Tumours. Geneva: World Health Organization; 1980: 22.

7. Epstein JI, Allsbrook WC Jr, Amin MB, Egevad LL. ISUP Grading Committee. The 2005 International Society of Urological Pathology (ISUP) Consensus Conference on Gleason Grading of Prostatic Carcinoma. Am J Surg Pathol 2005;29:1228-42.

8. Begum Z, Attar AK, Tengli MB, Ahmed MM. Study of Various Histopathological Patterns in Turp Specimens and Incidental Detection of Carcinoma Prostate. Indian Journal of Pathology and Oncology, October - December 2015;2(4);303-8.

9. Sharma A, Sharma M, Gandhi S, Khajuria A, Goswami KC. Histomorphological spectrum of prostatic lesions: a retrospective analysis of transurethral resection of prostate specimens. Int J Res Med Sci 2017;5:2373-8.

10. Puttaswamy K, Parthiban R, Shariff S. Histopathological Study of Prostatic Biopsies in Men with Prostatism. Journal of Medical Sciences and Health 2016; 2 (1): 11-7.

11. Bal MS, Kanwal S, Goyal AK, Singla N. Prostatic lesions in surgical biopsy specimens. JK Practitioner 2011;16(1-2):33-4.

12. Angurana N. Pattern of prostrate diseases- a histopathological study in Jammu. International Journal of Basic and Applied Medical Sciences 2014; 4(3): 163-7.

13. Bhat $\mathrm{S}$, Chaudhri S, Bhat $\mathrm{P}$, Hatwal D. Histopathological Study of Prostatic Diseases in Garhwal Region. Int J Sci Stud 2015;3(8):136140.

14. Bhatta S, Hirachan S. Prostatic lesions: histopathological study in a tertiary care hospital. JMMIHS.2018;4(1):12-19.

Copyright: (C) the author(s), 2019. It is an open-access article distributed under the terms of the Creative Commons Attribution License (CC BY 4.0), which permits authors to retain ownership of the copyright for their content, and allow anyone to download, reuse, reprint, modify, distribute and/or copy the content as long as the original authors and source are cited.

How to cite this article: Kumar D, Lal PK, Chaudhary PK, Singh RVN. Histopathological Study on Pattern of Prostatic Diseases in Patients Admitted at a Medical College. Asian J. Med. Res. 2019;8(1):PT05-PT07.

DOI: dx.doi.org/10.21276/ajmr.2019.8.1.PT2 